International Business and Global Economy 2018, no. 37, pp. 348-359

Biznes międzynarodowy w gospodarce globalnej 2018, nr 37, s. 348-359

Edited by the Institute of International Business, University of Gdańsk

Tomasz Sosnowski

Uniwersytet Łódzki

Anna Wawryszuk-Misztal

Uniwersytet Marii Curie-Skłodowskiej

\title{
Voluntary disclosure and quality of new stock companies' earnings forecast in EU-regulated markets
}

Companies conducting IPO in European countries make a voluntary decision regarding the disclosure of earnings forecast in prospectus. Using a sample of 651 companies that conducted IPO on EU-regulated markets between 2010 and 2016, we investigate the popularity of decisions on revealing financial forecasts in prospectus and address the questions regarding the type and accuracy of such forecasts. We find that only $12.58 \%$ of companies voluntarily included their financial forecasts in the IPO prospectus, and the scope of the disclosed information is diversified. Most commonly prospectuses include projections of sales revenues, net profits, and EBITDA. Our results give evidence that financial projections are over-optimistic and not accurate.

Keywords: financial forecasts accuracy, earnings forecast error, initial public offering, prospectus

JEL classification: G32, G39

\section{Ujawnianie oraz jakość prognozy zysku spółek debiutujących na europejskich regulowanych rynkach akcji}

W krajach europejskich przedsiębiorstwa realizujące pierwszą ofertę publiczną (IPO) mogą podjąć dobrowolną decyzję o tym, czy opublikować prognozę zysku w prospekcie emisyjnym. Opierając się na próbie 651 spółek giełdowych debiutujących na europejskich rynkach regulowanych w latach 2010-2016 poszukujemy odpowiedzi na pytania dotyczące rodzaju i trafności prognoz wyników finansowych opublikowanych w prospektach emisyjnych. Uzyskane wyniki wskazują, iż jedynie 12,58\% spółek zdecydowało się ujawnić prognozy finansowe w prospekcie emisyjnym, przy czym zakres ujawnianych informacji finansowych jest zróżnicowany. Najczęściej prospekty zawierają prognozy przychodów ze sprzedaży, zysku netto oraz EBITDA. Otrzymane wyniki pozwalają stwierdzić, że prognozy finansowe są zbyt optymistyczne i nietrafne.

Słowa kluczowe: trafność prognozy, błąd prognozy zysku, pierwsza oferta publiczna, prospekt emisyjny

Klasyfikacja JEL: G32, G39 


\section{Introduction}

Asymmetry of information between investors and managers is one of the relevant problems concerning investment decisions and the main source of risk incurred by potential shareholders in the public securities market. This problem arises especially at the time of initial public offering (IPO), with managers having private information about the company's future cash flows, investment opportunities, and their own managerial capital, and public investors having to deal with uncertainty because of their limited knowledge [Roosenboom, Goot, Mertens, 2003 , p. 243]. The decision to raise capital, especially through IPO, requires the issuer to undertake actions that will allow investors to obtain all relevant information about the company. Information disclosure is vital for the efficient functioning of capital markets, because it reduces information asymmetry and increases the level of disclosure associated with the decrease in the cost of capital [Bédard, Coulombe, Courteau, 2016, p. 236]. In the case of companies offering their securities to the public for the first time in a regulated public securities market, this information should be included in the prospectus and allow investors to determine what price they are willing to pay for the shares [Roosenboom, Goot, Mertens, 2003, p. 244].

In EU countries, the prospectus should be drawn up in accordance with Directive 2003/71/EC, which requires that the information included enable the investor to assess the issuer's assets and liabilities, financial position, profit, losses, and especially its prospects. Harmonization of the prospectus rules allows investors to obtain similar information on companies introducing their securities to the regulated market and ensures the same standard of investor protection across EU countries. The detailed information that should be included in the prospectus is specified by Commission Regulation (EC) No 809/2004 and Commission Delegated Regulation (EU) No 862/2012.

In this paper, we examine the issue of financial forecasts voluntarily disclosed in IPO prospectuses of companies that go public on EU-regulated stock exchanges. The prospectus rules allow the issuer to decide if he wants to disclose the forecast of future earnings in the document; if so, it should be presented in a consistent and comparable manner, accompanied by a statement prepared by independent accountants or auditors [EC, 2012]. Moreover, the prospectus should contain principal assumptions upon which the forecast is based and a report of independent accountants or auditors stating that "the forecast or estimate has been properly compiled on the basis stated and that the basis of accounting used for the profit forecast or estimate is consistent with the accounting policies of the issuer" [EC, 2012]. However, the existing rules do not specify the type of profit or forecast horizon or the way earnings forecasts are presented in the prospectus. 
Considering the rather general nature of the legal regulations regarding the disclosure of forward-looking information in the IPO prospectus and the fact that the decision on the inclusion of earnings forecasts is voluntary, the main aim of this paper is to answer two major questions. First, how popular is the decision to include financial forecasts in the prospectus among companies that go public in Europe? Second, what kind of information concerning financial forecasts do they disclose?

The second strand of our investigation assesses the accuracy of forwardlooking financial information revealed in the process of going public. Thus, the third question concerns management earnings forecast errors. Specifically, how the actual profits or other forecasted financial categories are different from their projections disclosed in the IPO prospectus. This issue is especially important as the credibility of financial information is an underlying assumption of all the research on accounting disclosure [Bédard, Coulombe, Courteau, 2016, p. 236]. Since the information included in the prospectus affects the offer price [Firth, 1998, p. 38] and is directly reflected in the proceeds from the sale of primary and secondary shares, we posit the following hypothesis:

$\mathrm{H}$ : In the IPO prospectuses of companies going public on EU-regulated stock exchanges there is a tendency to present overly optimistic forecasts of financial results.

Our key motivation for asking such questions in the present study is the lack of extensive cross-European empirical evidence relating to voluntary disclosure of information in the IPO process. A large body of literature has investigated this issue in other countries and, therefore, under different legal regimes. Existing studies on profit projections concern a wide range of issues from the importance of the voluntary decision to include earnings forecasts in IPO prospectus [Jog, McConomy 2003; Bédard, Coulombe, Courteau, 2016] to the determinants of earnings forecasts errors [Bédard, Coulombe, Courteau, 2008; Chen, Firth, Krishnan, 2001] and the consequences of disclosure of inaccurate projections [Jog, McConomy 2003; How, Yeo, 2001; Lonkani, Firth, 2005; Chen, Firth, Krishnan, 2001]. While earnings forecasts are used as a signal of company value, some researchers investigate also the association between earnings forecast and the post listing stock returns [Firth, 1998].

Empirical literature on earnings forecasts published by IPO companies on European stock exchanges is quite fragmented, rather limited, and outdated. Most of the existing research was carried out before the introduction of EU uniform rules on the prospectus. For example, Cazavan-Jeny and Jeanjean [2007] analyse 82 IPO prospectuses of French companies seeking to be listed on the Euronext Paris from 2000 to 2002 and report the negative correlation between the earnings forecast error and the level of detailed information included in the prospectus. 
Mnif [2009], using the sample of 117 French IPO firms between 2000 and 2004, examines the relation between corporate governance attributes and earnings forecasts accuracy. The research of Cormier and Martinez [2006] regards the association between management earnings forecasts, earnings management, and stock market valuation for 118 firms going public on Euronext Paris in 2000-2002. Schatt and Roy [2002], investigating 151 French new listings between 1996 and 2000, try to explain the earnings forecasts error and analyse its impact on the long-term stock return. The earnings forecasts accuracy for the French IPOs is also analysed by Citron, Cressy, and Gerard [2008] covering the period from 1996 to 2000 and by Degeorge and Derrien [2001] for the period of 1991-1998. For Danish IPOs, the issue of earnings forecasts is analysed in the context of earnings management by Gramlich and Sorensen [2004]. Using the sample of 58 companies they report that discretionary accruals are used by managers to reduce the earnings forecast error. In turn, Jelic [2001] deals with profit forecasts revealed by companies conducting IPO on the London Stock Exchange from 1981 to 2004 and concludes that voluntary disclosure of profit projections may affect the level of underpricing.

There is little empirical research on IPO earnings forecasts in European countries after 2004. The later research concerning Greek IPOs pays attention to the regulatory switch from mandatory to voluntary management earnings forecasts. Until 2001, the firms seeking to be listed on the Athens Stock Exchange were obliged to include their profit forecasts for the following year in the IPO prospectus. The comparison of forecasts published under these two regimes is the main subject of research of Gounopoulos, Kraft, and Skinner [2015] and Boubaker et al. [2017]. Their findings suggest that the mandatory disclosure requirement makes issuers bias profit forecasts downwards systematically as they opt for the safety of accounting conservatism. As far as French IPOs are concerned, covering the sample of 102 IPO prospectuses for companies going public on NYSE Euronext Paris between 2002 and 2010, the study of Hamammi and Sioud [2014] shows that earnings projections are too optimistic and earnings variability and financial leverage play an important role in explaining ex-post bias. Studies on Polish IPOs of Sosnowski and Wawryszuk-Misztal [2017a; 2017b] also confirm a relatively low accuracy of such forecasts and the excessive optimism regarding future financial results of new stock companies.

In pursuing our objectives, the remainder of this paper is organized as follows. The next section describes our sample and explains the methods of measuring forecast accuracy. Then, in the third section we provide the empirical results. The last section summarizes and concludes. 


\section{Research design}

\subsection{Sample}

Our initial sample consisted of 806 firms, based on the entire population of IPOs issued in the EU-regulated stock exchange markets over the period of 2010-2016. The subject of our interest are not companies whose first public listing was carried out on the so-called alternative, exchange-regulated stock markets (e.g. London AIM, Oslo Axess, Warsaw NewConnect), because such IPOs are small and have easier listing requirements than new firms in the main market of the European stock exchange.

We used the following filters to construct a final sample. First of all, to be included in the study sample, the IPO of the company had to be associated with sale to the public of primary shares issued by the company or secondary shares from the portfolio of the original shareholders. Further, we deleted companies previously listed on exchange-regulated stock markets and transferred to the main market as well as dual listings. In addition, companies from the banking and insurance sectors were excluded from the sample due to differences in their financial reporting requirements. We also required the prospectuses to be available. These criteria resulted in a final sample that comprises 651 IPOs with complete data.

In order to obtain the necessary information on financial forecasts, we analysed the content of hand-collected prospectuses of these IPOs. After omitting firms that decided not to disclosure any forecast, the study sample consists of 84 IPO firms. Table 1 provides the sample distribution across the EU-regulated stock markets and years.

Panel A of Table 1 reports the distribution of our sample across the European stock exchange main markets. The largest number of new listed companies is on the London Stock Exchange. Such IPOs account for slightly more than one-third of the whole sample. In addition, Warsaw Stock Exchange, Euronext, and Nasdaq OMX are also quite active. Among the whole sample only $12.58 \%$ of companies voluntarily included their financial forecasts in the IPO prospectus. The highest proportion of forecasters (34.55\%) is on the Polish stock exchange. Compared to other exchanges, Nasdaq OMX, Euronext, and Borsa Italiana also stand out, with the shares of forecasters at the level of $22.62 \%, 15.96 \%$, and $15.79 \%$, respectively. On other EU-regulated stock markets the share of companies publishing such forward-looking information is relatively small.

Panel B of Table 1 presents yearly frequencies of the analysed IPOs. The IPO market was most active in 2014 and 2015 and a substantial downturn was observed in 2012. The proportion of forecasters higher than the average in the whole 
sample was noted only in 2010 (17.57\%) and 2013 (14.77\%). In other years it does not vary widely overtime and is about $10.00 \%$ or slightly more.

Table 1. Sample description

\begin{tabular}{|c|c|c|c|}
\hline \multicolumn{4}{|c|}{ Panel A. IPO frequencies by market } \\
\hline EU-regulated market & Forecasters & $\begin{array}{l}\text { Non- } \\
\text {-forecasters }\end{array}$ & $\begin{array}{c}\% \text { of } \\
\text { forecasters }\end{array}$ \\
\hline Nasdaq OMX (main) & 19 & 65 & 22.62 \\
\hline London Stock Exchange (main and SFM) & 4 & 230 & 1.71 \\
\hline $\begin{array}{l}\text { Deutsche Börse (prime and general stan- } \\
\text { dard) }\end{array}$ & 1 & 46 & 2.13 \\
\hline Euronext & 15 & 79 & 15.96 \\
\hline Bolsa de Madrid (main) & 1 & 16 & 5.88 \\
\hline Borsa Italiana (main) & 3 & 16 & 15.79 \\
\hline Oslo Bors & 1 & 23 & 4.17 \\
\hline Warsaw Stock Exchange (main) & 38 & 72 & 34.55 \\
\hline Other markets* & 2 & 20 & 9.09 \\
\hline \multicolumn{4}{|c|}{ Panel B. IPO frequencies by year } \\
\hline Year & Forecasters & $\begin{array}{c}\text { Non- } \\
\text {-forecasters }\end{array}$ & $\begin{array}{c}\% \text { of } \\
\text { forecasters }\end{array}$ \\
\hline 2010 & 14 & 60 & 18.92 \\
\hline 2011 & 9 & 63 & 12.50 \\
\hline 2012 & 6 & 44 & 12.00 \\
\hline 2013 & 13 & 75 & 14.77 \\
\hline 2014 & 14 & 116 & 10.77 \\
\hline 2015 & 19 & 132 & 12.58 \\
\hline 2016 & 9 & 77 & 10.47 \\
\hline
\end{tabular}

Notes: * Athens Stock Exchange, Wiener Börse, Irish Stock Exchange, Zagreb Stock Exchange, Budapest, Bucharest, Sofia, Prague, Luxembourg, SIX Swiss Exchange.

Source: Own elaboration.

\subsection{Measurement of financial forecast accuracy}

The research on the accuracy of financial forecasts disclosed in various types of corporate documents uses a wide range of measures expressing the scale of forecast errors [Sosnowski, Wawryszuk-Misztal, 2017a]. Taking into account the information value of the particular forecast error measures, the research questions we ask, and the availability of data concerning the analysed companies, to achieve the research objective we use two most commonly applied intuitive indicators of the forecast error that are especially popular in business forecasting. 
Our first forecast accuracy measure, forecast error (FER), shows how much the actual value of a given financial category varies from its predicted value; it is computed as the difference between the actual value of the variable for the IPO year and its forecast value as given in the prospectus scaled to the absolute value of forecast:

$$
F E R=\frac{\text { Actual }- \text { Forecast }}{\mid \text { Forecast } \mid}
$$

This indicator allows assessing the scale of the forecast error and determining its nature, i.e., whether the financial forecast turned out to be optimistic or pessimistic. FER can take both positive and negative values. For instance, in the case of financial projections of earnings or sales, the positive value of this measure shows that the prediction disclosed in the prospectus was conservative and too pessimistic. Conversely, a negative value is obtained when the company prepared an over optimistic forecast and the actual value of profit or sales was lower than the forecasted one.

Our second measure of the IPO prospectus forecast accuracy is the absolute forecast error (AFER) that is equal to the absolute value of FER:

$$
\text { AFER } \mid \text { FER } \mid=\frac{\mid \text { Actual }- \text { Forecast } \mid}{\mid \text { Forecast } \mid}
$$

The value of AFER shows how much of the actual value of a given financial category differs from its prediction, regardless of whether the error is due to overor underestimation of the forecast. While the FER metric indicates the direction of the bias of the forecast error, AFER indicates the overall level of goodness of fit [Lonkani, Firth, 2005, pp. 269-286].

The financial statement data required to assess the accuracy of the forecasts for the year of going public are hand-collected either from annual reports or from other publications.

\section{Empirical results}

The analysis of the empirical data on the scope of financial forecasts included in the IPO prospectuses indicates that issuers interpret very freely the legal provision referring to the disclosure of forward-looking financial information. Figure 1 shows that the time range of forecasts usually covers the IPO year. As far as various financial categories of the projection are concerned, one can notice a significant variety of the presented information. 


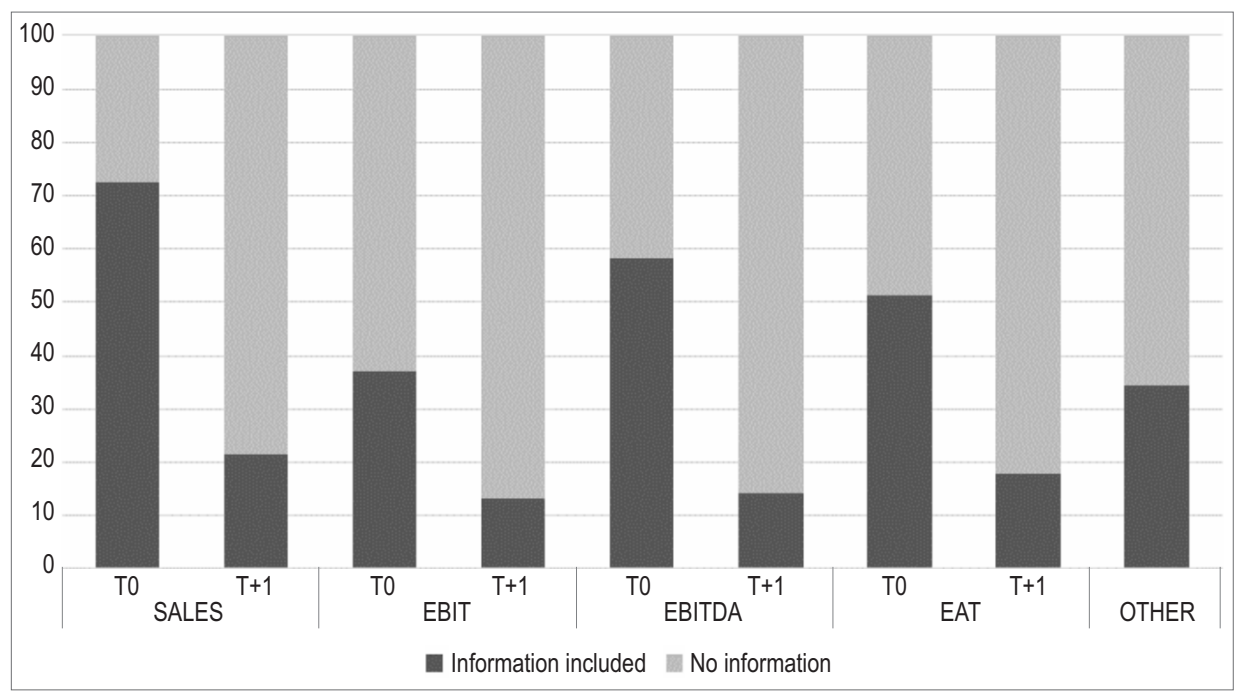

Figure 1. Main financial categories whose forecasts are disclosed in IPO prospectuses across EU-regulated stock markets (\%)

Notes: The analysed companies may forecast more than one financial category.

Source: Own elaboration.

Companies going public most often publish information about the forecasted sales revenues (SALES), earnings before interest, taxes, depreciation, and amortization (EBITDA), as well as earnings after taxes (EAT). In addition, a part of the analysed forecasts includes information on the expected level of earnings before deducting interest and taxes (EBIT).

However, a detailed qualitative analysis of the disclosed forecasts revealed a limited information value of some of them. Some companies do not provide precise information, but confine to fairly general statements relating to the expected trends. For example, some companies treat expressions like "we expect a slight increase in sales" as a profit forecast, present the expected value in a given range or without the impact of the planned corporate events such as a takeover or IPO. Some issuers include financial forecasts only for selected segments of their business activity. Moreover, their easy approach to the term "profit forecast" is evidenced by the fact that some of them decide to disclose a number of other, not result-based pieces of information in this section of the prospectus. For example, one can find information about the expected rate of margin on net income, funds from operations, the amount of comprehensive income or cash, as well as the expected value of various financial ratios. Sometimes the information is presented descriptively in a very general manner without any details. In contrast, some forecasters present full forward-looking financial statements for the year of IPO and subsequent years. 
Such attitude of issuers towards disclosing financial forecasts in the IPO prospectus slightly reduces the scale of the information gap in the process of issuing and selling shares to the public for the first time. Nevertheless, it should be noted that against the new stock companies on other EU-regulated markets, IPOs from the Warsaw Stock Exchange show significant conservatism in terms of the content and usefulness of information revealed in profit forecasts, which is characterized by a noteworthy precision of formulations, repeatability in form, detail, and comparability.

The next part of the research is aimed at answering the question about the accuracy of financial forecasts disclosed in the IPO prospectuses. Due to the goal of the study and the content of the analysed forecasts, which in many cases made it impossible to precisely calculate the measures assessing their accuracy, further research work is limited to the analysis of the accuracy of forecasts prepared for the IPO year (T0) in the most often presented financial categories, i.e., SALES, EBIT, EBITDA, and EAT. The study covers only those companies that precisely define the forecasted value of a given financial category ${ }^{1}$. Table 2 presents the descriptive statistics of the accuracy measures of the analysed financial forecasts.

Table 2. Descriptive statistics of error indicators for the forecasted financial categories

\begin{tabular}{|c|c|c|c|c|c|c|c|}
\hline $\begin{array}{c}\text { Forecasted } \\
\text { category }\end{array}$ & $\begin{array}{c}\text { Error } \\
\text { measure }\end{array}$ & Mean & Median & $\begin{array}{l}\text { Standard } \\
\text { deviation }\end{array}$ & Min & Max & $\mathrm{N}$ \\
\hline \multirow{2}{*}{ SALES } & FER & $\begin{array}{c}-0.0099 \\
(-0.1633) \\
\end{array}$ & $\begin{array}{l}-0.0184 \\
(-1.467) \\
\end{array}$ & 0.4256 & -0.9900 & 2.0885 & \multirow{2}{*}{49} \\
\hline & AFER & $\begin{array}{c}0.2244 \\
(4.3599)^{* * *}\end{array}$ & $\begin{array}{c}0.0809 \\
(6.093)^{* * *}\end{array}$ & 0.3603 & 0.0009 & 2.0885 & \\
\hline \multirow{2}{*}{ EBIT } & FER & $\begin{array}{c}-0.1861 \\
(-1.9967)^{*}\end{array}$ & $\begin{array}{c}-0.0713 \\
(-2.095)^{* *} \\
\end{array}$ & 0.4931 & -2.0933 & 0.5484 & \multirow{2}{*}{28} \\
\hline & AFER & $\begin{array}{c}0.3154 \\
(3.9793)^{* * *}\end{array}$ & $\begin{array}{c}0.2296 \\
(4.623)^{* * *}\end{array}$ & 0.4194 & 0.0104 & 2.0933 & \\
\hline \multirow{2}{*}{ EBITDA } & FER & $\begin{array}{c}-0.1059 \\
(-1.3066) \\
\end{array}$ & $\begin{array}{l}-0.0409 \\
(-1.305) \\
\end{array}$ & 0.4929 & -1.7747 & 1.0019 & \multirow{2}{*}{37} \\
\hline & AFER & $\begin{array}{c}0.2848 \\
(4.1876)^{* * *}\end{array}$ & $\begin{array}{c}0.1174 \\
(5.303)^{* * *}\end{array}$ & 0.4136 & 0.0018 & 1.7747 & \\
\hline \multirow{2}{*}{ EAT } & FER & $\begin{array}{c}-0.2466 \\
(-1.9831)^{*}\end{array}$ & $\begin{array}{c}-0.0353 \\
(-1.976)^{* *}\end{array}$ & 0.7963 & -2.2543 & 1.8366 & \multirow{2}{*}{41} \\
\hline & AFER & $\begin{array}{c}0.5014 \\
(4.8471)^{* * *}\end{array}$ & $\begin{array}{c}0.2822 \\
(5.579)^{* * *}\end{array}$ & 0.6624 & 0.0044 & 2.2543 & \\
\hline
\end{tabular}

Notes: One sample t-statistics of t-test for mean and non-parametric Z-statistic of Wilcoxon test for median are reported in parentheses. ${ }^{* *}, * *$, and $*$ indicate significance at the $1 \%, 5 \%$, and $10 \%$ level, respectively. If the forecasts are unbiased and accurate, the mean or median of forecast error measures should not be significantly different from zero. Source: Own elaboration.

1 Prior to conducting the analysis, we removed from the sample one company as an outlier, namely Allterco AD-Sofia. 
The negative mean and median values of FER for all analysed financial categories lead to the conclusion that the forecasts published in the prospectuses are generally too optimistic. The forecast of sales revenues is characterized by a higher accuracy in comparison to other forward-looking information. The average (median) forecast error amounts only to $-0.99 \%(-1.84 \%)$ and, according to statistical tests, is not statistically different form zero ( $p$-value 0.1$)$. The descriptive statistics of AFER for SALES indicate that the financial projections for this category are characterized by the highest accuracy.

The least accurate are the forecasts regarding the expected net profit. FER for EAT varies between -2.2543 and 1.8366 , with a standard deviation of 0.7963 . The mean (median) FER is $-24.66 \%(-3.53 \%)$. Taking into account the statistical significance of the results, one can conclude that management tend to systematically over-predict net profits. Moreover, in the case of EAT, AFER is significantly greater than zero, which shows that the profit forecasts are generally not accurate.

Overall, these results indicate an information advantage of the prediction prepared for sales revenues in comparison with the EBIT, EBITDA, and EAT forecasts.

\section{Conclusions}

The paper empirically investigated the scope and accuracy of forward-looking financial information disclosed in IPO prospectuses of new stock companies across EU-regulated public securities markets. The data allowed us to draw the following main conclusions. First, a relatively small part of the IPOs decide to use financial forecasts as a tool to limit the information gap in the process of going public.

Second, as a result of the existing legal regulations relating to the publication of financial projections in the IPO process, the scope of information presented in this part of the prospectus is very diversified, both in terms of the type of forecasted financial categories and the period of prediction. Most often companies decide to provide stock market investors with information on the forecasted sales revenues, net profits, earnings before interest, taxes, depreciation, and amortization.

Third, there are some differences in the level of accuracy of the financial projections of these financial categories. Although our findings provide a general conclusion that forecasts revealed in the IPO prospectuses are over-optimistic and not accurate, the obtained results indicate that the forecast of sales revenue is flawed by the smallest prediction error, and thus it has the greatest information value for investors making a decision to purchase the company's shares in the IPO. 


\section{References}

Bédard J., Coulombe D., Courteau L., 2008, Audit committee, underpricing of IPOs, and accuracy of management earnings forecasts, Corporate Governance: An International Review, vol. 6 .

Bédard J., Coulombe D., Courteau L., 2016, The credibility of earnings forecasts in IPO prospectuses and underpricing, Account Perspectives, vol. 4.

Boubaker S., Gounopoulos D., Kallias A., Kallias K., 2017, Management earnings forecasts and IPO performance: Evidence of a regime change, Review of Quantitative Finance and Accounting, vol. 4.

Cazavan-Jeny A., Jeanjean T., 2007, Levels of voluntary disclosure in IPO prospectuses: An empirical analysis, Review of Accounting and Finance, vol. 2.

CEC, 2004, Commission of the European Communities, Commission Regulation (EC) No 809/2004 of 29 April 2004 implementing Directive 2003/71/EC of the European Parliament and of the Council as regards information contained in prospectuses as well as the format, incorporation by reference and publication of such prospectuses and dissemination of advertisements, http://ec.europa.eu/internal_market/securities/ docs/prospectus/reg-2004-809/reg-2004-809_en.pdf [access: 26.08.2018].

Chen G., Firth M., Krishnan G.V., 2001, Earnings forecast errors in IPO prospectuses and their associations with initial stock returns, Journal of Multinational Financial Management, vol. 2.

Citron D., Cressy R., Gerard X., 2009, Prospectus forecast publication and forecast errors: The role of venture capitalist certification, Venture Capital, vol. 2.

Cormier D., Martinez I., 2006, The association between management earnings forecasts, earnings management, and stock market valuation: Evidence from French IPO, The International Journal of Accounting, vol. 41.

Degeorge F., Derrien F., 2001, IPO performance and earnings expectations: Some French evidence, Working paper, HEC Paris.

EC, 2012, European Commission, Commission Delegated Regulation (EU) No 862/2012 of 4 June 2012 amending Regulation (EC) No 809/2004 as regards information on the consent to use of the prospectus, information on underlying indexes and the requirement for a report prepared by independent accountants or auditors, https://eur-lex. europa.eu/LexUriServ/LexUriServ.do?uri=OJ:L:2012:256:0004:0013:EN:PDF [access: 26.08.2018].

EP, 2003, European Parliament, Directive 2003/71/EC of the European Parliament and of the Council of 4 November 2003 on the prospectus to be published when securities are offered to the public or admitted to trading and amending Directive 2001/34/EC, L 345/64 Official Journal of the European Union EN 31.12.2003, https://eur-lex.europa. eu/legal-content/EN/TXT/PDF/?uri=CELEX:32003L0071\&from=en [access: 26.08.2018].

Firth M., 1998, IPO profit forecasts and their role in signaling firm value and explaining post-listing returns, Applied Financial Economics, vol. 1.

Gounopoulos D., Kraft A., Skinner F., 2015, Voluntary vs. mandatory management earnings forecasts in IPOs, Economics and Finance Working Paper Series, Working Paper No. 15-12. Brunel University London, https://www.brunel.ac.uk/_data/assets/pdf_ file/0016/421144/1512.pdf [access: 18.01.2018]. 
Gramlich J.D., Sorensen O., 2004, Voluntary management earnings forecasts and discretionary accruals: Evidence from Danish IPOs, European Accounting Review, vol. 2.

Hammami M., Sioud O.B., 2014, The reliability of management earnings forecasts in IPO prospectuses: A study of managers' forecasting preferences, International Scholarly and Scientific Research \& Innovation, vol. 6.

How J.C.Y., Yeo J.J.L., 2001, The impact of forecast disclosure and accuracy on equity pricing: The IPO perspective, Journal of Accounting, Auditing, and Finance, vol. 4.

Jelic R., 2011, Management forecasts and IPO performance, Working Paper, University of Birmingham, United Kingdom.

Jog V.J., McConomy R.J., 2003, Voluntary disclosure of management earnings forecasts in IPO prospectuses, Journal Business Finance \& Accounting, vol. 1.

Lonkani R., Firth M., 2005, The accuracy of IPO profit forecasts in Thailand and their relationships with stock market valuation, Accounting and Business Research, vol. 3 .

Mnif A., 2009, Corporate governance and management earnings forecast quality: Evidence from French IPOs, La place de la dimension européenne dans la Comptabilité Contrôle Audit, Strasbourg, France.

Roosenboom P., Goot T.V., Mertens G., 2003, Earnings management and initial public offerings: Evidence from the Netherlands, The International Journal of Accounting, vol. 3.

Schatt A., Roy T., 2002, Analyse empirique des ecarts de previsions de Benefices dans les prospectus d'introduction: Le cas francais, Technologie et management de l'information: Enjeux et impacts dans la comptabilite, le controle et l'audit, France.

Sosnowski T., Wawryszuk-Misztal A., 2017a, Zróżnicowanie prognozowanych informacji finansowych zawartych w prospektach emisyjnych spótek przeprowadzajacych pierwsze oferty publiczne na GPW w Warszawie, Przedsiębiorczość i Zarządzanie, vol. 7.

Sosnowski T., Wawryszuk-Misztal A., 2017b, Trafność prognoz wyniku finansowego i ich wptyw na zmiany wartości rynkowej nowych spótek giełdowych, Finanse, vol. 1.

T. Sosnowski (ब) tomasz.sosnowski@uni.lodz.pl

Wydział Ekonomiczno-Socjologiczny, Uniwersytet Łódzki, ul. POW 3/5, 90-255 Łódź, Polska

A. Wawryszuk-Misztal (-) anna.wawryszuk@umcs.pl Wydział Ekonomiczny, Uniwersytet Marii Curie-Skłodowskiej, Pl. M. Curie-Skłodowskiej 5, 20-031 Lublin, Polska 